\title{
Setaria worms from the domestic pigs in Burma
}

\author{
by THA KHIN * and KHIN KHIN WIN ** \\ * Veterinary and Animal Husbandry Department, Rangoon, Burma. \\ ** Part of the thesis submitted for M.Sc. degree.
}

SUMMARY. Setaria thomasi Sandosham, 1954, which was described originally in Malaysia, is reported in domestic pigs of Burma. The species is redescribed.

\section{Sétaires de porcs domestiques en Birmanie,}

RESUME. Setaria thomasi Sandosham, 1954, décrite initialement de Malaisie, est retrouvée chez des porcs domestiques de Birmanie, et redécrite.

\section{Introduction}

One male and seven female Setaria thomasi Sandosham, 1953, were obtained from the folds of the omentum in the peritoneal cavity of seven domestic pigs out of 480 examined. Except two female worms, which were found from one host, all others were found singly in different hosts. The specimens were fixed and preserved in 70 percent alcohol and cleared in lactophenol for examination. All the drawings were made with the aid of camera lucida.

\section{Setaria thomasi Sandosham, 1954}

\section{Description :}

Body long, milky-white in colour and attenuated towards the extremities. Posterior extremity more attenuated than anterior extremity and coiled. Mouth aperture oval laterally and surrounded by protruding chitinuous peribuccal ring. Four pairs of submedian papillae and a pair of lateral amphids present near cephalic extremity. Excretory pore behind nerve ring. Two small cervical papillae, each with a single spine, located laterally

Accepté le 12 juin 1980. 

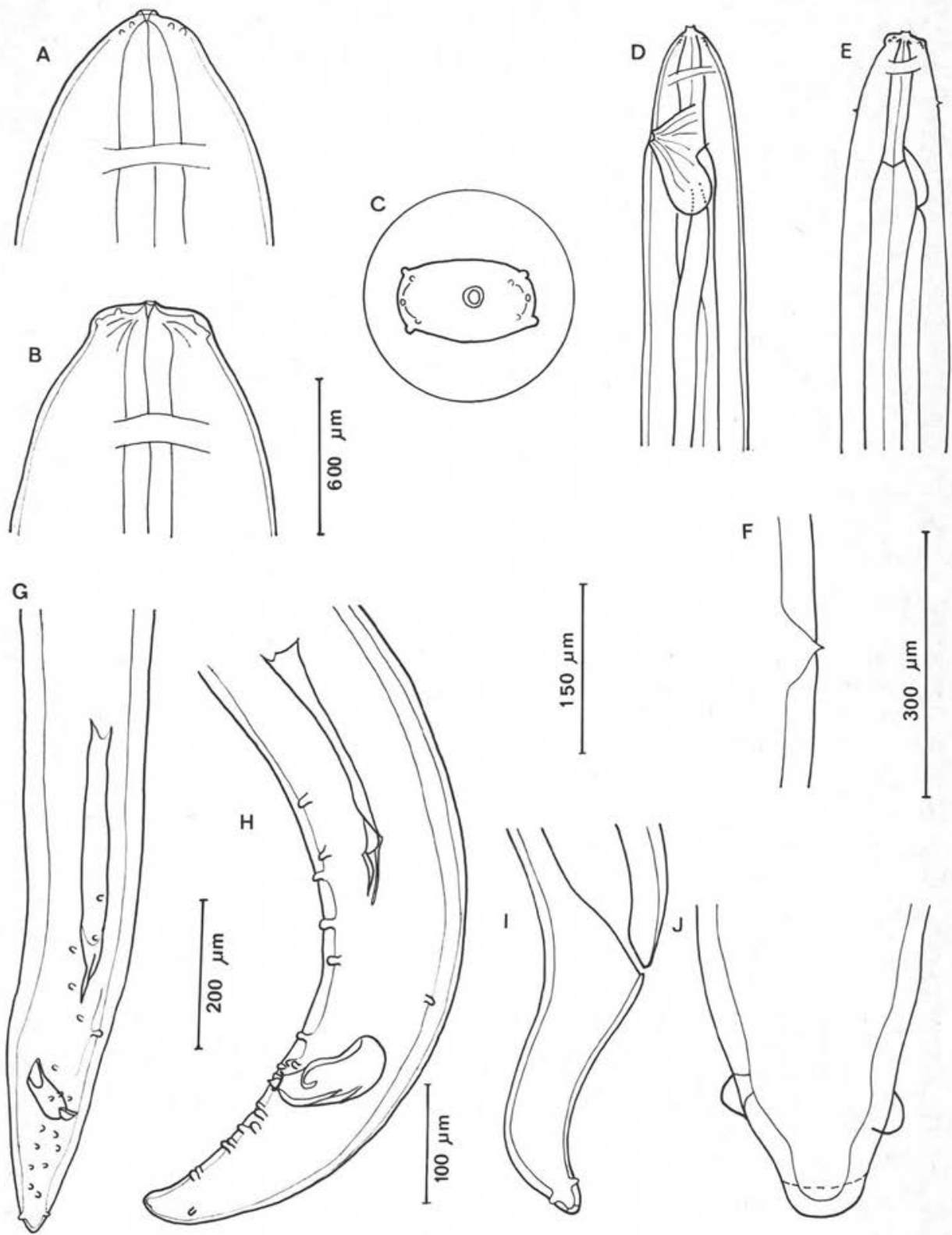

Fig. 1. Setaria thomasi Sandosham, 1954. A, head of female, lateral aspect; B, id., median aspect; C, id., en-face aspect; D, anterior end of female, lateral aspect; E, id., median aspect; F, deirid; $\mathrm{G}$, male posterior end, ventral aspect; $\mathrm{H}$, id., lateral aspect; I, female posterior end; J, id., enlarged. A, G, scale: $200 \mu \mathrm{m}$; B, C, I, scale: $300 \mu \mathrm{m}$; D, E, $600 \mu \mathrm{m}$; H, scale: $100 \mu \mathrm{m}$; J, F, scale: $150 \mu \mathrm{m}$. 
posterior to nerve ring. Esophagus clearly divided into anterior muscular and posterior glandular portions, the latter being much longer than the former and slightly greater in diameter. A pair of small lateral deirids lies closely towards the posterior extremity.

Male:

Body $60 \mathrm{~mm}$ long, $0,41 \mathrm{~mm}$ wide. The oval peribuccal ring equally high, is $0,02 \mathrm{~mm}$ in lateral aspect. Anterior muscular portion of oesophagus 0,48 mm long, 0,07 wide; posterior glandular portion $5,28 \mathrm{~mm}$ long, $0,32 \mathrm{~mm}$ wide. Nerve ring, excretory pore and cervical papillae situated $0,15 \mathrm{~mm}, 0,22 \mathrm{~mm}$ and $0,41 \mathrm{~mm}$, respectively, from anterior end.

Tail $0,18 \mathrm{~mm}$ long, slightly attenuated with rounded tip bearing two small phasmids on each side of the body $0,015 \mathrm{~mm}$ from posterior end. A number of transverse striations present on ventral surface anterior to caudal papillae. Caudal papillae include four pairs of precloacal papillae, a median papilla just in front of the cloaca and four pairs of postcloacal papillae on the ventral surface. First three pairs of precloacal papillae tend to be asymmetrically arranged. Spicules unequal and dissimilar; left spicule long, slender and attenuated towards posterior portion. Left spicule $0,29 \mathrm{~mm}$ long with shaft $0,22 \mathrm{~mm}$ and distal portion $0,07 \mathrm{~mm}$ long. Right spicule $0,13 \mathrm{~mm}$ in length, stout and tapering towards the posterior end. A posterior deirid located dorsolaterally about $0,29 \mathrm{~mm}$ from caudal extremity on left side.

\section{Females:}

Body 100-114 mm long; 0,53-0,59 mm wide. Peribuccal ring measures 20,88-24,36 $\mu \mathrm{m}$ laterally. Muscular portion of oesophagus $0,45-0,56 \mathrm{~mm}$ long, 0,07-0,09 mm wide; glandular portion 9,97-12,03 $\mathrm{mm}$ long and $0,22-0,33 \mathrm{~mm}$ wide. Nerve ring, excretory pore and cervical papillae situated $0,18-0,19 \mathrm{~mm}, 0,22-0,25 \mathrm{~mm}$ and $0,32-0,38 \mathrm{~mm}$ respectively from the anterior end. Vulva $0,43-0,62 \mathrm{~mm}$ from anterior end. Vagina and ovejector directed posteriorly and joining uterus near end of oesophagus. Uterus divided into two posteriorly directed branches $11,4-16,16 \mathrm{~mm}$ from anterior end. Uteri of two female worms contain numerous microfilariae $153,12-198,36 \mu \mathrm{m}$ in length and $6,96 \mu \mathrm{m}$ in width. A posterior deirid located dorsalaterally $1,3-2 \mathrm{~mm}$ from caudal extremity on left side. Tail rounded, $0,28-0,38 \mathrm{~mm}$ long; a pair of small phasmids located $0,03-0,06 \mathrm{~mm}$ from caudal extremity.

Host: domestic pigs (Sus scrofa domesticus).

Habitat: peritoneal cavity.

Locality: Irrawaddy Division (Burma).

\section{Discussion}

Four species of the genus Setaria have been recorded from Suidae. (1) Setaria congolensis Railliet and Henry, 1911, from the warthog, bushpig and domestic pigs, all of Africa. (2) S. bernardi Railliet and Henry, 1911, from the domestic pig of Annan and from wild boar of different parts of Asia (India, Ceylon, Celebes, Taiwan, Japan and Eastern Siberia). This species was recorded by Chatterji (1939) and Griffiths (1957) from the domestic pig of Burma, and it was redescribed by Durette-Desset (1966). (3) S. castroi Ortlepp, 1964 from the warthog and the bushpig of Mozambique and East Africa. (4) S. thomasi Sandosham 1954, from a wild boar, Sus scrofa jubatus of Malaysia. The description of this last species was based upon 3 males and 5 females from one host. This species was regarded as incertae sedis by Yeh (1959); however Bain and Shoho (1978) gave a redescription of one female worm from a wild boar of the type locality. Comparing the data of other authors with our 
own, some differences are found in the length of the body, the length of male tail and number of caudal papillae. The body length of our specimens $(60 \mathrm{~mm}$ for the male and $100-114 \mathrm{~mm}$ for the females) exceeds that reported by Sandosham $(48-57 \mathrm{~mm}$ for the males and $54-95 \mathrm{~mm}$ for females) and Bain and Shoho (76 $\mathrm{mm}$ for a female). The male tail length and the number of its caudal papillae reported by Sandosham differ from our findings, but this may be because Sandosham observed specimens only in lateral view. Because of the asymmetrically arrangement of the first three pairs of sexual papillae, number cannot be counted exactly unless a ventral examination is made. Thus Sandosham reported 14 pairs of caudal papillae instead of the 8 pairs and one unpaired caudal papillae and one pair of phasmids observed in the present study. With the present description $S$. thomasi, a Seteria species from Suidae with an oval peribuccal chitinous ring has been clearly demonstrated in the Far East. The report of Bain and Shoho is supplemental with the detail of a male on the modern standard.

ACKNOWLEDGEMENTS. - We are greatly indebted to Dr Ko Ko Gyi, Professor of Zoology Department, Arts and Science University, Rangoon, Burma, for his encouragment and providing the research facilities. We wish to express our appreciation to Dr Chuzaburo Shoho, former F.A.O. Animal Health Officer, Somalia, for giving suggestions and kindly supplying the references.

\section{References}

Bain O., Shoho C.: Sur deux Filaires d'Ongulés en Malaisie. Ann. Parasitol. Hum. Comp., 1978, 53, 93-100.

Chatterji R.C.: Report on two unrecorded nematode parasites from domesticated animals of India or Burma. Indian J. Vet. Sci., 1939, 9, 323-332.

Durette-Desset M.-C.: Contribution à la systématique des Filaires du genre Setaria; valeur des deirides. Mém. Mus. natn. Hist. nat. Paris, sér. A, 1966, 39, 257-287.

Griffiths R. B. : Report to the Government of Burma on Parasitic disease of livestock. Food and Agriculture Organization of the United Nations, $\mathrm{n}^{\circ} 684,1957$.

Ortlepp R. J.: Observations on helminths parasitic in warthogs and bushpigs. Onderstepoort J. Vet. Res., 1964, 31, 11-38.

Railliet A., Henry A.: Sur une Filaire péritonéale des Porcins. Bull. Soc. Path. Exot., 1911, 4, 386-389.

Railliet A., Henry A.: Sur une Filaire. Remarques au sujet des deux notes de MM. Bauche et Bernard. Bull. Soc. Path. Exot., 1911, 4, 485-488.

Sandosham A. A. : Malaysian parasites. XV. Seven new worms from miscellaneous hosts. Stud. Inst. Med. Res. Malaya, 1954, $\mathrm{n}^{\circ}$ 26, 212-226.

Yeh L.S.: A revision of the nematode genus Setaria Viborg, 1795, its host-parasite relationship, speciation and evolution. J. Helminth., 1959, 33, 1-98. 